\title{
PENGARUH KONDISI TANAH ASAM DAN CACAT GORES BERBENTUK PERSEGI PANJANG PADA LAPIS LINDUNG TERHADAP KEBUTUHAN ARUS PROTEKSI SISTEM IMPRESSED CURRENT CATHODIC PROTECTION (ICCP) DENGAN MENGGUNAKAN BAJA AISI 1045
}

\author{
Tubagus Noor Rohmannudin, Sulistijono, Faris Putra Ardiansyah \\ Jurusan Teknik Material dan Metalurgi, Fakultas Teknologi Industri, Institut Teknologi Sepuluh \\ Nopember (ITS) \\ Jalan Arief Rahman Hakim, Surabaya 60111 \\ roma_r2001@yahoo.com
}

\begin{abstract}
Corrosion is degradation of the metal due to an oxidation reaction between the metal with many substances that exist in the environment around them and form undesirable compounds. Corrosion can not be prevented, but still can be controlled its speed. One of the corrosion control process in a material can be used a coating and cathodic protection by providing a forced flow. At this time the research conducted will learn about the effect of the rectangular scratch defect and the acid soil pH to the needs of current protection in the impressed current cathodic protection system (ICCP). The variation of given scratch is rectangular with each area of $10 \mathrm{~mm}^{2}, 50 \mathrm{~mm}^{2}, 100 \mathrm{~mm}^{2}, 150 \mathrm{~mm}^{2}, 250 \mathrm{~mm}^{2}$ and $500 \mathrm{~mm}^{2}$. While the differences in soil $\mathrm{pH}$ use is $\mathrm{pH} 3, \mathrm{pH} \mathrm{5}$, and $\mathrm{pH}$ 7. Then there is also a specimen without scratch and without layers of protection that is used as a comparison. In the ICCP system installation, AISI 1045 steel is used as the cathode and graphite as the anode. The system used a rectifier that is useful for current rectifier. The flow of the ICCP protection is set such that the value of the potential difference can reach $-850 \mathrm{mV}$ against the reference electrode $\mathrm{Cu} / \mathrm{CuSO}$. Measurement of the current protection on the ICCP system performed during the 7 days with daily data retrieval. After obtained the measurement of the current protection value, showed that the greatest current protection value with $500 \mathrm{~mm}^{2}$ defect area in acidic soils (pH 3) that is equal to $1.696 \mathrm{~mA}$. While the smallest current protection in area of $10 \mathrm{~mm}^{2}$ with normal soil that is equal to $0.032 \mathrm{~mA}$. The influence of these two variables were calculated using multiple regression statistical analysis so as to get the equation $Y=0,11+0,008 X_{1}+0,0004$ $X_{2}$. Where the value of $X_{1}$ as soil $p H$ conditions, $X_{2}$ as scratch defect, and $Y$ as current protection.
\end{abstract}

Keywords:Acid Soil pH, AISI 1045 Steel, ICCP, Protection Current, Rectangular Scratch Defect

\section{PENDAHULUAN}

Penggunaan struktur yang terbuat dari besi dan baja kini memiliki peranan yang sangat penting dalam dunia industri terutama pada penggunaan untuk saluran air, saluran gas, maupun tiang konstruksi. Struktur yang diaplikasikan pada kegiatan tersebut didesain sedemikian rupa agar dapat dipakai hingga 30-50 tahun. Namun pada kenyataannya timbul banyak permasalahan yang menyebabkan turunnya kualitas baja tersebut hingga terjadi kerusakan yang sangat parah.
Hal ini dikarenakan korosi yang menjadi penyebab utama terhadap kegagalan material dimana dampak yang ditimbulkan akan berimbas pada lingkungan dan ekonomi. Oleh karena itu, berbagai upaya terus dilakukan guna untuk mempertahankan masa pemakaian yang lebih lama dan sesuai standar.

Selain itu, kondisi pada struktur yang dipendam didalam tanah dapat membuat masalah menjadi lebih kompleks. Pada umumnya, korosi pada tanah dapat dibatasi dengan pengukuran resistivitas tanah dan 
potensial struktur terhadap tanah. Namun setelah diteliti kembali masih terdapat banyak faktor yang dapat menyebabkan timbulnya korosi pada tanah, diantaranya ialah jenis tanah, kelembaban, $\mathrm{pH}$ tanah, dan cacat/goresan pada baja yang dapat menimbulkan korosi sumuran. Pelapisan (Coating) menjadi solusi untuk menjaga kestabilan dan penghalang terhadap lingkungan korosif untuk mengurangi laju degradasi. Lapisan tambahan diberikan untuk mengisolasi struktur agar terhindar dari lingkungan luar yang dapat menimbulkan korosi.

Namun pada kenyataannya, tak jarang saat proses pemasangan coating terdapat ketidaksempurnaan sehingga timbul goresan atau sobekan. Usaha lain yang dapat dilakukan untuk mengendalikan korosi ialah dengan menggunakan proteksi katodik metode Impressed Current Cathodic Protection (ICCP). Sistem proteksi ini dapat melindungi baja yang relatif besar dengan memberikan sejumlah arus secara paksa yang dapat diatur sesuai dengan kebutuhan. Dengan keuntungan yang lebih fleksibel dalam mengendalikan korosi pada struktur baja konstruksi yang melatarbelakangi penulis untuk melakukan penelitian ini. Pada penelitian ini akan dibahas karakteristik tanah pada tingkat keasaman yang berbedabeda terhadap kebutuhan arus proteksi yang dibutuhkan oleh struktur baja yang dipendam didalam tanah. Selain itu, variabel lain yang diteliti ialah variasi cacat gores yang diberikan pada lapis lindung diharapkan memiliki pengaruh pada kebutuhan proteksi katodik.

\section{METODOLOGI PENELITIAN}

Proteksi katodik digunakan untuk mengendalikan korosi pada permukaan logam. Proses yang dilakukan biasanya berupa reaksi elektrokimia dimana logam yang dilindungi akan bertindak sebagai katoda. Arus mengalir berasal dari anoda melalui sel elektrolit menuju ke katoda. Sehingga kemampuan proteksi terhadap katoda dapat dicapai dengan mengalirkan arus listrik tersebut. Bahan-bahan yang digunakan dalam penelitian ini adalah baja AISI 1045 yang mempunyai komposisi seperti pada tabel 1. Anoda grafit yang berfungsi sebagai anoda dipilih karena memiliki laju konsumsi yang rendah dan tergolong dalam logam yang inert. Untuk coating/lapis lindung yang digunakan adalah cat zinc chromate dan epoxy filler dengan tambahan hardener. Dan yang terakhir untuk mengubah kondisi $\mathrm{pH}$ tanah dapat ditambahkan dengan larutan aquades yang dicampurkan dengan $\mathrm{HCl}$ untuk mengubah tanah menjadi asam.

Tabel 1.

Komposisi Kimia Baja AISI 1045

\begin{tabular}{|c|c|}
\hline Unsur & \% berat \\
\hline $\mathrm{C}$ & 0,45 \\
\hline $\mathrm{Si}$ & 0,25 \\
\hline $\mathrm{Mn}$ & 0,6 \\
\hline $\mathrm{P}$ & 0,01 \\
\hline $\mathrm{S}$ & 0,002 \\
\hline $\mathrm{Cu}$ & 0,04 \\
\hline
\end{tabular}

Tabel 2.

Spesifikasi Anoda Grafit

\begin{tabular}{|l|l|}
\hline Spesifikasi & Keterangan \\
\hline Kategori & $\begin{array}{l}\text { Impregnated Epoxy } \\
\text { Resin }(\mathrm{H})\end{array}$ \\
\hline Model & $\mathrm{M} 120 \mathrm{H}$ \\
\hline Bentuk & Tubular \\
\hline Dimensi & $\begin{array}{l}\mathrm{p}=138 \mathrm{~mm} ; \mathrm{d}=36 \\
\mathrm{~mm}\end{array}$ \\
\hline Massa pakai & 20 tahun \\
\hline $\begin{array}{l}\text { Komposisi } \\
\text { Kimia }\end{array}$ & $\begin{array}{l}99.8 \% \text { Carbon; } \\
0.2 \% \text { Ash }\end{array}$ \\
\hline Laju konsumsi & $0.1-1 \mathrm{~kg} /$ A.Year \\
\hline
\end{tabular}

Langkah penelitian ini diawali dengan preparasi baja yang bertindak sebagai katoda. Baja dipotong menjadi 24 bagian dengan gergaji mesin hingga mendapatkan dimensi masing-masing panjang $100 \mathrm{~mm}$ dan diameter $20 \mathrm{~mm}$. Melubangi spesimen katoda dengan mengebor salah satu ujungnya untuk tempat pemasangan kabel katoda. Pembuatan tanda goresan dapat dilakukan seperti pada gambar 1 . 


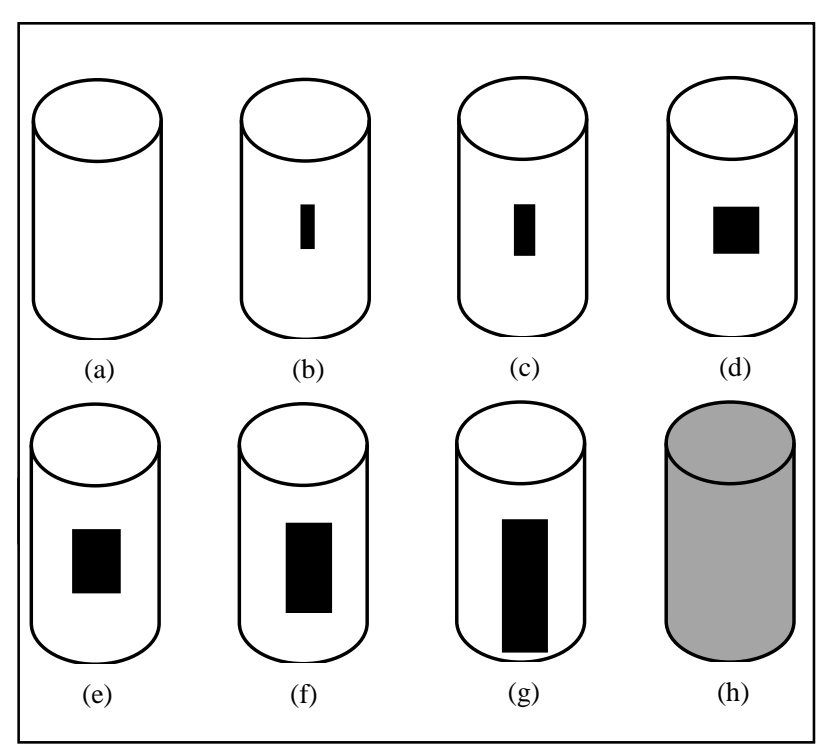

Gambar 1. Ilustrasi Spesimen Katoda dengan Goresan Berbentuk Persegi Panjang Seluas: (a) 0 $\mathrm{mm}^{2}$ (Full Coating), (b) $10 \mathrm{~mm}^{2}$, (c) $50 \mathrm{~mm}^{2}$, (d) $100 \mathrm{~mm}^{2}$, (e) $150 \mathrm{~mm}^{2}$, (f) $250 \mathrm{~mm}^{2}$, (g) 500 $\mathrm{mm}^{2}$, (h) Tanpa Coating

Langkah selanjutnya dengan melakukan pelapisan cat zinc chromate dan epoxy filler sebanyak 2 lapis. Untuk anoda grafit dipotong hingga berukuran tebal $\pm 10 \mathrm{~mm}$ dan dengan diameter $36 \mathrm{~mm}$. Katoda dan anoda dihubungkan melalui kabel tembaga dengan rectifier sebagai penyearah arus. Kabel tembaga pada baja dihubungkan ke kutub negatif (-) rectifier sedangkan kabel tembaga pada anoda grafit dihubungkan ke kutub positif (+) rectifier. Rangkaian menggunakan dua avometer untuk menghitung potensial kerja dan arus dalam rangkaian ICCP.

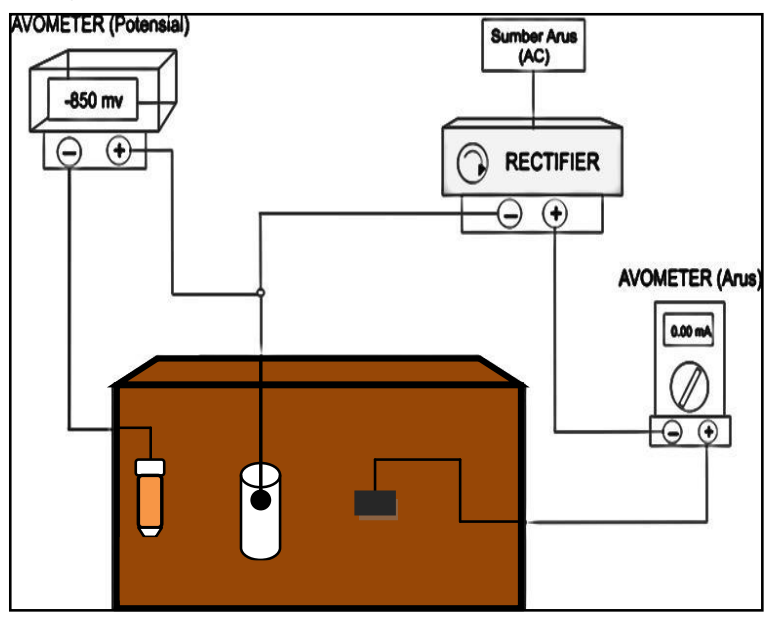

Gambar 2. Rangkaian ICCP
Pada penelitian ini menggunakan media tanah yang berbeda-beda. Terdapat 3 perbedaan $\mathrm{pH}$ tanah yang akan diujikan. Pengambilan media tanah yang berbeda ini dimaksudkan untuk mengetahui tingkat kebutuhan arus proteksi yang dibutuhkan pada lingkungan tanah yang asam hingga netral. Untuk mengubah $\mathrm{pH}$ tanah menjadi asam dapat ditambahkan dengan larutan Asam Klorida ( $\mathrm{HCl})$ sesuai dengan kebutuhan.

Rangkaian yang telah dipasang dapat diukur kebutuhan arus proteksi yang digunakan pada sistem ICCP ini. Metode pengukuran yang digunakan mengacu kepada half-cell potensial (potensial elektroda setengah sel). Elektroda acuan yang digunakan pada sistem ini adalah elektroda acuan $\mathrm{Cu} / \mathrm{CuSO}_{4}$. Dengan mendapatkan nilai potensial terhadap elektroda acuannya, maka arus proteksi yang digunakan dapat diatur dengan sedemikian rupa sehingga nilai potensial yang bekerja pada spesimen dapat berada dalam kondisi imun/dapat terproteksi.

Penelitian dilakukan untuk mengetahui nilai arus proteksi dengan melakukan pengukuran setiap hari selama 7 hari. Hal ini mengacu pada standard NACE TM01692000 "Laboratory Corrosion Testing of Metals”. Data arus proteksi pada sistem didapatkan setelah arus tersebut diatur sehingga nilai potensial yang bekerja berada pada $-850 \mathrm{mV}$ dimana baja akan mulai terproteksi. Pengukuran dilakukan pengulangan sebanyak 3 kali agar mendapatkan nilai arus proteksi yang lebih tepat dan pengukuran tersebut diambil nilai rata-ratanya.

\section{HASIL DAN PEMBAHASAN}

Pengukuran potensial awal dilakukan pada baja AISI 1045 sebelum instalasi ICCP dinyalakan. Nilai potensial awal ini berfungsi untuk mengetahui nilai potensial sebelum dan sesudah instalasi ICCP yang selanjutnya dapat digunakan sebagai patokan untuk menentukan arus proteksinya. 
Tabel 3.

Hasil Nilai Potensial Awal

(a) Kondisi Tanah pH 3

\begin{tabular}{|c|c|c|}
\hline $\begin{array}{c}\text { pH } \\
\text { Tanah }\end{array}$ & $\begin{array}{c}\text { Luas Goresan } \\
(\mathrm{mm} 2)\end{array}$ & $\begin{array}{c}\text { Potensial } \\
\text { Korosi (-mV) }\end{array}$ \\
\hline \multirow{7}{*}{} & 10 & 755 \\
\cline { 2 - 3 } & 50 & 730 \\
\cline { 2 - 3 } 3 & 100 & 745 \\
\cline { 2 - 3 } & 150 & 710 \\
\cline { 2 - 3 } & 250 & 702 \\
\cline { 2 - 3 } & 500 & 698 \\
\cline { 2 - 3 } & $\begin{array}{c}\text { Tanpa } \\
\text { Goresan }\end{array}$ \\
\cline { 2 - 3 } & Tanpa Coating & 778 \\
\hline
\end{tabular}

(b) Kondisi Tanah pH 5

\begin{tabular}{|c|c|c|}
\hline $\begin{array}{c}\text { pH } \\
\text { Tanah }\end{array}$ & $\begin{array}{c}\text { Luas Goresan } \\
(\mathrm{mm} 2)\end{array}$ & $\begin{array}{c}\text { Potensial } \\
\text { Korosi (-mV) }\end{array}$ \\
\hline \multirow{7}{*}{} & 10 & 763 \\
\cline { 2 - 3 } & 50 & 746 \\
\cline { 2 - 3 } 5 & 100 & 744 \\
\cline { 2 - 3 } & 150 & 712 \\
\cline { 2 - 3 } & 250 & 705 \\
\cline { 2 - 3 } & 500 & 713 \\
\cline { 2 - 3 } & $\begin{array}{c}\text { Tanpa } \\
\text { Goresan }\end{array}$ & 779 \\
\cline { 2 - 3 } & Tanpa Coating & 714 \\
\hline
\end{tabular}

(c) Kondisi Tanah $\mathrm{pH} 7$

\begin{tabular}{|c|c|c|}
\hline $\begin{array}{c}\mathrm{pH} \\
\text { Tanah }\end{array}$ & $\begin{array}{c}\text { Luas Goresan } \\
(\mathrm{mm} 2)\end{array}$ & $\begin{array}{c}\text { Potensial } \\
\text { Korosi (-mV) }\end{array}$ \\
\hline \multirow{4}{*}{} & 10 & 776 \\
\cline { 2 - 3 } & 50 & 755 \\
\cline { 2 - 3 } & 100 & 764 \\
\cline { 2 - 3 } & 150 & 739 \\
\cline { 2 - 3 } & 250 & 718 \\
\cline { 2 - 3 } & 500 & 723 \\
\cline { 2 - 3 } & $\begin{array}{c}\text { Tanpa } \\
\text { Goresan }\end{array}$ \\
\cline { 2 - 3 } & Tanpa Coating & 782 \\
\hline
\end{tabular}

Setelah mengukur potensial awal, maka rangkaian ICCP dapat dinyalakan dengan mengatur keluaran arus sehingga potensial kerja berada pada $-850 \mathrm{mV}$ dimana baja dapat terproteksi. Hasil akhir yang didapatkan berupa nilai rata-rata arus proteksi sebagai berikut :
Tabel 4.

Hasil Pengukuran Rata-Rata Arus Proteksi (a) Kondisi Tanah pH 3

\begin{tabular}{|c|c|c|}
\hline $\begin{array}{c}\mathrm{pH} \\
\text { Tanah }\end{array}$ & $\begin{array}{c}\text { Luas Goresan } \\
(\mathrm{mm} 2)\end{array}$ & $\begin{array}{c}\text { Arus Proteksi } \\
(\mathrm{mA})\end{array}$ \\
\hline \multirow{4}{*}{} & 10 & 0,038 \\
\cline { 2 - 3 } & 50 & 0,076 \\
\cline { 2 - 3 } 3 & 100 & 0,182 \\
\cline { 2 - 3 } & 150 & 0,712 \\
\cline { 2 - 3 } & 250 & 1,292 \\
\cline { 2 - 3 } & 500 & 1,696 \\
\cline { 2 - 3 } & $\begin{array}{c}\text { Tanpa } \\
\text { Goresan }\end{array}$ & 0,023 \\
\cline { 2 - 3 } & Tanpa Coating & 3,595 \\
\hline
\end{tabular}

(b) Kondisi Tanah pH 5

\begin{tabular}{|c|c|c|}
\hline $\begin{array}{c}\mathrm{pH} \\
\text { Tanah }\end{array}$ & $\begin{array}{c}\text { Luas Goresan } \\
(\mathrm{mm} 2)\end{array}$ & $\begin{array}{c}\text { Arus Proteksi } \\
(\mathrm{mA})\end{array}$ \\
\hline \multirow{4}{*}{} & 10 & 0,034 \\
\cline { 2 - 3 } & 50 & 0,047 \\
\cline { 2 - 3 } & 100 & 0,081 \\
\cline { 2 - 3 } & 150 & 0,096 \\
\cline { 2 - 3 } & 250 & 0,336 \\
\cline { 2 - 3 } & 500 & 0,577 \\
\cline { 2 - 3 } & $\begin{array}{c}\text { Tanpa } \\
\text { Goresan }\end{array}$ & 0,020 \\
\cline { 2 - 3 } & Tanpa Coating & 3,452 \\
\hline
\end{tabular}

(c) Kondisi Tanah $\mathrm{pH} 7$

\begin{tabular}{|c|c|c|}
\hline $\begin{array}{c}\mathrm{pH} \\
\text { Tanah }\end{array}$ & $\begin{array}{c}\text { Luas Goresan } \\
(\mathrm{mm} 2)\end{array}$ & $\begin{array}{c}\text { Arus Proteksi } \\
(\mathrm{mA})\end{array}$ \\
\hline \multirow{4}{*}{} & 10 & 0,032 \\
\cline { 2 - 3 } & 50 & 0,040 \\
\cline { 2 - 3 } & 100 & 0,061 \\
\cline { 2 - 3 } 7 & 150 & 0,077 \\
\cline { 2 - 3 } & 250 & 0,093 \\
\cline { 2 - 3 } & 500 & 0,142 \\
\cline { 2 - 3 } & $\begin{array}{c}\text { Tanpa } \\
\text { Goresan }\end{array}$ & 0,014 \\
\cline { 2 - 3 } & Tanpa Coating & 1,949 \\
\hline
\end{tabular}

Berdasarkan data rata-rata arus proteksi yang telah didapatkan maka hasil yang ada dilanjutkan dengan memplotkan hingga didapatkan grafik sebagai berikut : 


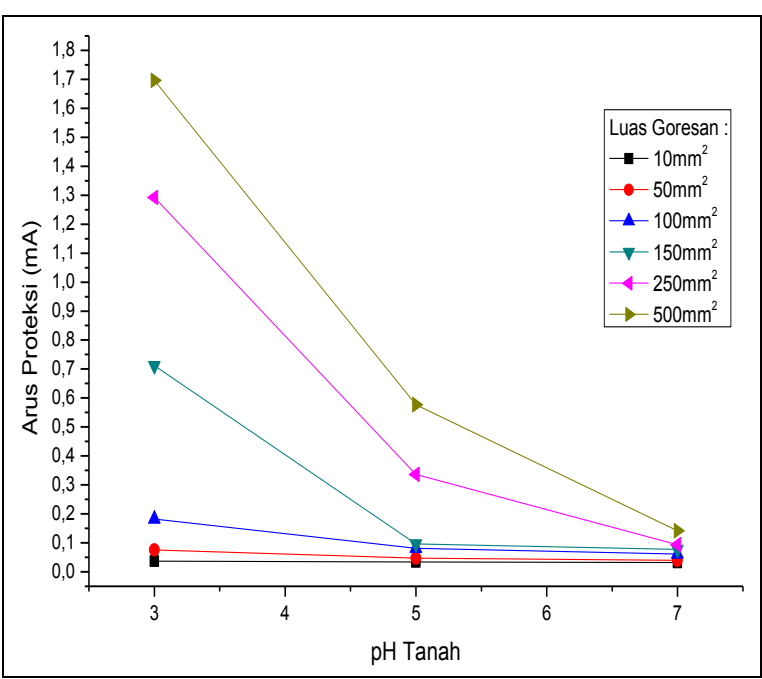

Gambar 3. Grafik Pengaruh Arus Proteksi Terhadap Kondisi pH Tanah

Dengan kondisi cacat goresan yang sama, berdasarkan grafik tersebut dapat dilihat bahwa pemasangan instalasi ICCP didalam tanah dengan nilai $\mathrm{pH}$ yang semakin asam maka dibutuhkan nilai arus proteksi yang semakin tinggi, sebaliknya apabila kondisi tanah memiliki kecenderungan menuju ke daerah basa maka arus proteksi yang dibutuhkan semakin kecil. Pada kondisi baja yang tidak tertutup oleh lapis lindung, arus proteksi pada kondisi tanah dengan $\mathrm{pH} 3$ membutuhkan 3,595 mA. Sedangkan pada pH 5 membutuhkan arus 3,452 mA dan untuk pH 7 membutuhkan arus 1,949 mA. Selisih kenaikan arus proteksi yang dibutuhkan cukup tinggi. Dari tanah dengan kondisi netral $(\mathrm{pH} \mathrm{7)}$ menuju ke kondisi yang cukup asam ( $\mathrm{pH}$ 5) terjadi peningkatan sebesar 43,54\%. Sedangkan tanah dengan kondisi cukup asam (pH 5) menuju ke kondisi yang asam ( $\mathrm{pH}$ 3) terjadi peningkatan sebesar 3,97\%. Hal ini disebabkan karena pada kondisi tanah yang memiliki $\mathrm{pH}<4$ akan memiliki tingkat agresifitas korosi yang sangat tinggi. Sehingga untuk melindungi baja tersebut diperlukan keluaran arus proteksi yang besar pula. Pada kondisi tanah dengan $\mathrm{pH}$ lebih dari 4 memiliki kemampuan untuk membentuk lapisan pasif yang bersifat protektif pada permukaan logam. Lapisan ini biasanya terbentuk dari oksida logam yang berfungsi sebagai pemisah antara logam dengan lingkungannya.

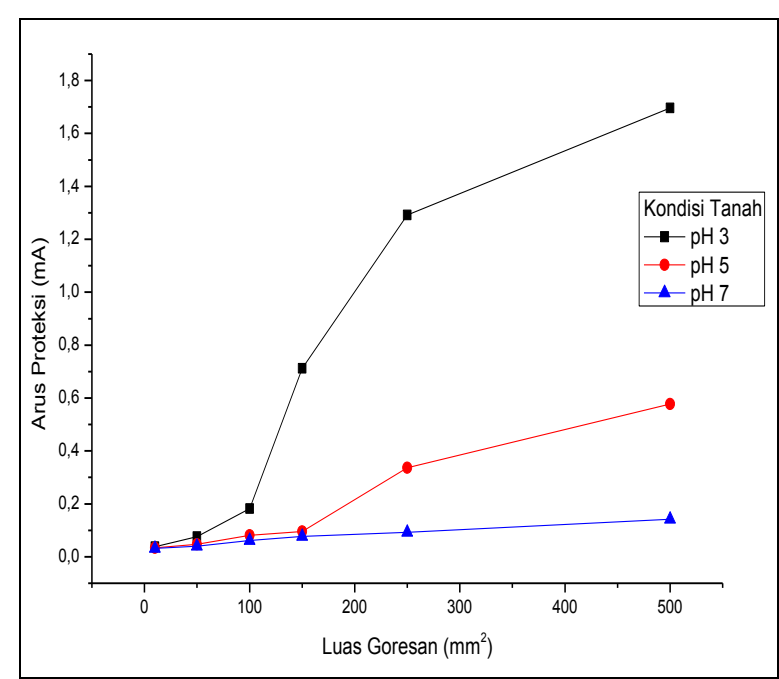

Gambar 4. Grafik Pengaruh Arus Proteksi Terhadap Variasi Cacat Goresan

Pengukuran arus proteksi dilanjutkan dengan membandingkan terhadap variasi cacat goresan yang diberikan. Pada kondisi $\mathrm{pH}$ tanah yang sama, semakin besar luas goresan yang diberikan pada baja maka akan semakin besar pula arus proteksi yang diberikan. Sebagai contoh pada kondisi tanah dengan $\mathrm{pH} 7$, telah diberikan cacat goresan dengan luasan $10 \mathrm{~mm}^{2}, 50 \mathrm{~mm}^{2}, 100$ $\mathrm{mm}^{2}, 150 \mathrm{~mm}^{2}, 250 \mathrm{~mm}^{2}$, dan $500 \mathrm{~mm}^{2}$. Arus yang diberikan secara berturut-turut adalah 0,032 mA; 0,04 mA; 0,061 mA; 0,077 mA; 0,093 mA; dan 0,142 mA. Hal ini dapat terjadi akibat adanya daerah pada permukaan logam yang terekspos langsung dengan lingkungannya. Sehingga dapat mengakibatkan terjadinya reaksi oksidasi yang berlanjut dengan adanya inisiasi korosi. Oleh karena itu, dibutuhkan pasokan elektron yang semakin tinggi guna menghindari terjadinya korosi yang lebih parah.

Analisa selanjutnya dengan menggunakan metode statistika. Untuk menentukan adanya suatu hubungan variabel sebabnya yaitu $\mathrm{pH}$ tanah dan variasi cacat goresan terhadap variabel terikat untuk arus proteksinya.

$$
\mathrm{Y}=0,11+0,008 \mathrm{X}_{1}+0,0004 \mathrm{X}_{2}
$$

Dimana nilai $\mathrm{X}_{1}$ untuk kondisi $\mathrm{pH}$ tanah dari kondisi tanah $\mathrm{pH} 3$ hingga $\mathrm{pH} 7, \mathrm{X}_{2}$ untuk luas cacat goresan dengan rentan luas $0 \mathrm{~mm}^{2}$ hingga $6908 \mathrm{~mm}^{2}$, dan Y untuk arus proteksi dalam satuan $\mathrm{mA}$. Untuk menguji kekuatan pengaruh dari kondisi $\mathrm{pH}$ tanah 
dan variasi cacat goresan terahadap arus proteksi, digunakan uji korelasi pearson dan uji korelasi berganda. Dari hasil uji korelasi pearson didapatkan bahwa hubungan antara kondisi $\mathrm{pH}$ tanah dengan kebutuhan arus proteksi memiliki kategori yang sedang sebesar $0,381(0,2<\mathrm{r}<0,4)$. Sedangkan untuk variabel variasi cacat goresan terhadap kebutuhan arus memiliki hubungan yang kuat yaitu sebesar $0,735(0,6<\mathrm{r}<0,8)$

Perhitungan dilanjutkan mendapatkan nilai korelasi berganda sebesar 0,828. Artinya pengaruh yang ditimbulkan oleh kedua variabel ini sangatlah kuat, sehingga apabila $\mathrm{pH}$ tanah dan variasi cacat goresan memiliki nilai yang tinggi maka secara otomatis nilai arus proteksi yang dibutuhkan akan semakin tinggi. Adapun kontribusi secara simultan kedua variabel tersebut sebesar : $(0,828)^{2} \mathrm{x}$ $100 \%=69 \%$.

\section{KESIMPULAN}

Berdasarkan pada penelitian yang telah dilakukan maka dapat disimpulkan bahwa :

1. Terdapat pengaruh yang ditimbulkan oleh kondisi $\mathrm{pH}$ tanah yang berbeda-beda terhadap kebutuhan arus proteksinya. Dengan membandingkan pada luas cacat goresan yang sama, arus proteksi yang dibutuhkan pada baja akan semakin turun dengan meningkatnya derajat keasaman tanah dari $\mathrm{pH} 3$ hingga $\mathrm{pH} 7$

2. Sama halnya dengan $\mathrm{pH}$ tanah, variasi cacat goresan pada lapis lindung dapat mempengaruhi nilai proteksi yang diberikan pada baja. Pada kondisi $\mathrm{pH}$ tanah yang sama, arus proteksi yang dibutuhkan cenderung meningkat seiring meluasnya cacat goresan yang diberikan.

\section{DAFTAR PUSTAKA}

Bardal, Einar. 2003. Corrosion and Protection. Trondheim : Norway

Bofardi, B.P. 1985. Control of Environmental Wariables in Water Recirculating Systems. New Jersey : Noyes Publications

Callister, W. 2006. Fundamentals of Materials Science and Engineering
Seventh Edition. USA : John Wiley \& Sons Inc

Chemical Composition of AISI 1045. Diakses tahun 2014. (Online) Available at http//www.strindustries.com

Fontana, Mars G. 1996. Corrosion Engineering $2^{\text {nd }}$ Edition. Singapore: McGraw-Hill International.

NACE SP0169-2007, Control of External Corrosion on Undergrounf or Submerged Metallic Piping Systems. Diakses tahun 2014. (Online) Available at http//www.nace.org

NACE TM 0169-95. Laboratory Corrosion Testing of Metals

Peabody, A.W. 2001. "Control of Pipeline Corrosion," Edited by Ronald L Bianchetti, Texas: NACE International the Corrosion Society

Shobah, M. Nurus. 2014. Pengaruh Goresan Lapis Lindung dan Salinitas Air Laut Terhadap Arus Proteksi Sistem Impressed Current Cathodic Protection (ICCP) pada Pipa API 5L Grade B," Tugas Akhir Jurusan Teknik Material dan Metalurgi, Fakultas Teknologi Industri, Institut Teknologi Sepuluh Nopember Surabaya.

Wu, J. Dkk. 2009. The Influence of Coating Damage on The ICCP Cathodic Protection Effect. Luoyang Ship Material Research Institute. P.R.China 